\title{
ACTIVE FAULTING AND DEFORMATION OF QUATERNARY LANDFORM SUB-HIMALAYA, INDIA
}

\author{
GIRISH CH. KOTHYARI ${ }^{1}$, P. D. PANT ${ }^{2}$, MOULISHREE JOSHI ${ }^{3}$, KHAYINGSHING LUIREI ${ }^{4}$ \\ and JAVED N. MALIK ${ }^{5}$ \\ ${ }^{I}$ Institute of Seismological Research, Gandhinagar, Gujarat, India \\ ${ }^{2}$ Department of Geology, Kumaun University Nainital, India \\ ${ }^{3}$ Petroleum and Renewable Energy Engineering, Universiti Teknologi Malaysia, 81310 UTM, Skudai, Johor, Malaysia \\ ${ }^{3}$ Wadia Institute of Himalayan Geology, Dehradun, India \\ ${ }^{4}$ Indian Institute of Technology, Kanpur, India
}

Received 15 January 2010

Accepted 15 September 2010

\begin{abstract}
Landforms developed across terrain defining boundary the Main Boundary Thrust (MBT) have imprints of recent tectonic activity. Depositional landforms such as colluvial fan bear signatures of later phases of tectonic activity in the form of faulting of colluvial fan deposits and development of fault scarps. Tectonic geomorphology applied to the MBT zone suggests recent subsurface activity along the MBT and its splay thrusts. Present day tectonic activity of MBT is indicated by ground creeping, thrusting of Lower Siwalik rocks over recent colluvial fan deposit, aligning of series of lakes along splay faults and laterally along a fault, deflected streams, fault scarps and waterfalls. In the present paper we are addressing the tectonic situation in the foothill region of southeastern $\mathrm{Ku}$ maun Sub-Himalaya, India based on detailed field work carried out in the region which brought forward some outstanding morphotectonic evidence of neotectonic activities in the MBT zone.
\end{abstract}

Keywords: Quaternary landform, Kumaun Sub-Himalaya, neotectonics, fault scarps, colluvial fan, tectonic lakes

\section{INTRODUCTION}

The Himalayan range is one of the most active Intracontinental range in the world (Lave and Avouac, 2000) Active tectonic movements in the Himalaya mainly along the Main Frontal Thrust (MFT) and Main Boundary Thrust MBT are very common (Hodges et al., 2004; Lave and Avouac, 2000; Wobus, et al. 2003; Valdiya, 2003). In the Himalayan region, the accumulated strain energy is linked to the subsurface internal deformation of rocks under thrusting along the detachment surface (Kayal, 2001; Seeber et al., 1981). The central segment of the Kumaun Lesser Himalaya is seismically very active (Bilham et al., 1998; Bilham and Gaur, 2000; Pollitz et al., 2008). The geomorphic development in the Himalaya is a result of the interaction between climate and tectonics (Molnar, 2003; Starkel, 2003; Srivastava and Misra, 2008). The neotectonic activities in the frontal margin of Kumaun Himalaya are attributed to the formation out of

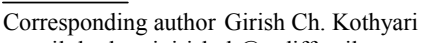

e-mail: kothyarigirish_k@rediffmail.com

ISSN 1897-1695 (online), 1733-8387 (print) @ 2010 GADAM Centre, Institute of Physics, Silesian University of Technology.

All rights reserved. sequence thrusts and erosion leading to isostatic adjustments (Bookhagen et al., 2005; Hodges et al., 2004; Wobus et al., 2006). As the active deformation in $\mathrm{Ku}-$ maun Himalaya appears to be concentrated along the MBT, this study focuses on the geomorphic development of southern Kumaun Himalayan Siwalik in response to the neotectonic movements.

The MBT is defined as a boundary between the SubHimalaya and the Lesser Himalaya. It places metasedimentary rocks of the Lesser Himalaya of Middle to Late Proterozoic rocks with granites dated as $1900 \pm 100 \mathrm{Ma}$ and 500 $\pm 2 \mathrm{Ma}$ (Valdiya, 2001) (Fig. 1a) over the unmetamorphosed clastic rocks of the Siwalik Group of the Sub-Himalaya of Neogene age (Meigs et al., 1995; Hodges et al., 1996; Macfarlane, 1993). The $1500 \mathrm{~km}$ long MBT of the Himalayan range runs from Arunachal Pradesh in the east to Kashmir in the west (Khwaja and Khwaja, 2005). The sediment accumulation rate and analytical data (palaeomagnetism and geomagnetic polarity data) collected from northwestern India and Pakistan suggest initial displacement along $>1000 \mathrm{~km}$ of the MBT prior to $10 \mathrm{Ma}$, until at least $5 \mathrm{Ma}$ (Meigs et al., 1995). 
Apatite fission-track ages from structures at the leading edge of the Main Boundary Thrust in the Kohat region of northwest Pakistan indicate that rapid cooling below $\sim 105^{\circ} \mathrm{C}$ between 8 and $10 \mathrm{Ma}$ followed bedrock uplift and erosion that began $\sim 1-2$ Ma earlier (Meigs et al., 1995). These data indicate that the MBT in the western Himalaya formed synchronously along the strike during the middle-late Miocene, and has a displacement rate of $\sim 10 \mathrm{~mm} / \mathrm{yr}$, (Meigs et al., 1995; Burbank and Raynolds, 1988). Thermoluminescence date of the fault gouge obtained from Kumaun Himalaya suggests that the MBT reactivated during $70 \pm 17$ ka (Banerjee et al., 1999; Singhvi et al., 1994). Measurements made by some workers show that the present day movement along Himalayan front is of the order of $0.92 \mathrm{~cm} / \mathrm{yr}$, however, horizontal shortening is estimated $5.8 \pm 1.8$ (Malik and Nakata 2003; Kumar, et al., 2006).

\section{MAIN BOUNDARY THRUST (MBT)}

The MBT, separating the Siwalik Formations of the sub-Himalayas from the older rocks lying to their north, is a major structural plane discernible throughout the length of the Himalayas (Khwaja and Khwaja, 2005; Nakata, 1972; Nakata and Kumhara, 2000). Hitherto regarded as a steep north dipping fault, it is more likely a thrust which becomes shallower with depth. The MBT, originally defined as the tectonic feature separating the Siwalik Formations from the pre Siwalik Tertiary, is exposed only in the extreme western sector in the $\mathrm{Ku}$ maun Himalayas, roughly between the Yamuna and Tons valleys (Fig. 1a). East of Yamuna, the Higher Krol Thrust has overlapped the Eocene Subathu and has completely concealed the MBT. The only exception is seen near Durgapipal in the east where a narrow belt of Subathu is exposed between the Siwalik and overthrust Krol rocks (Valdiya, 2003). Secondary faults or thrusts

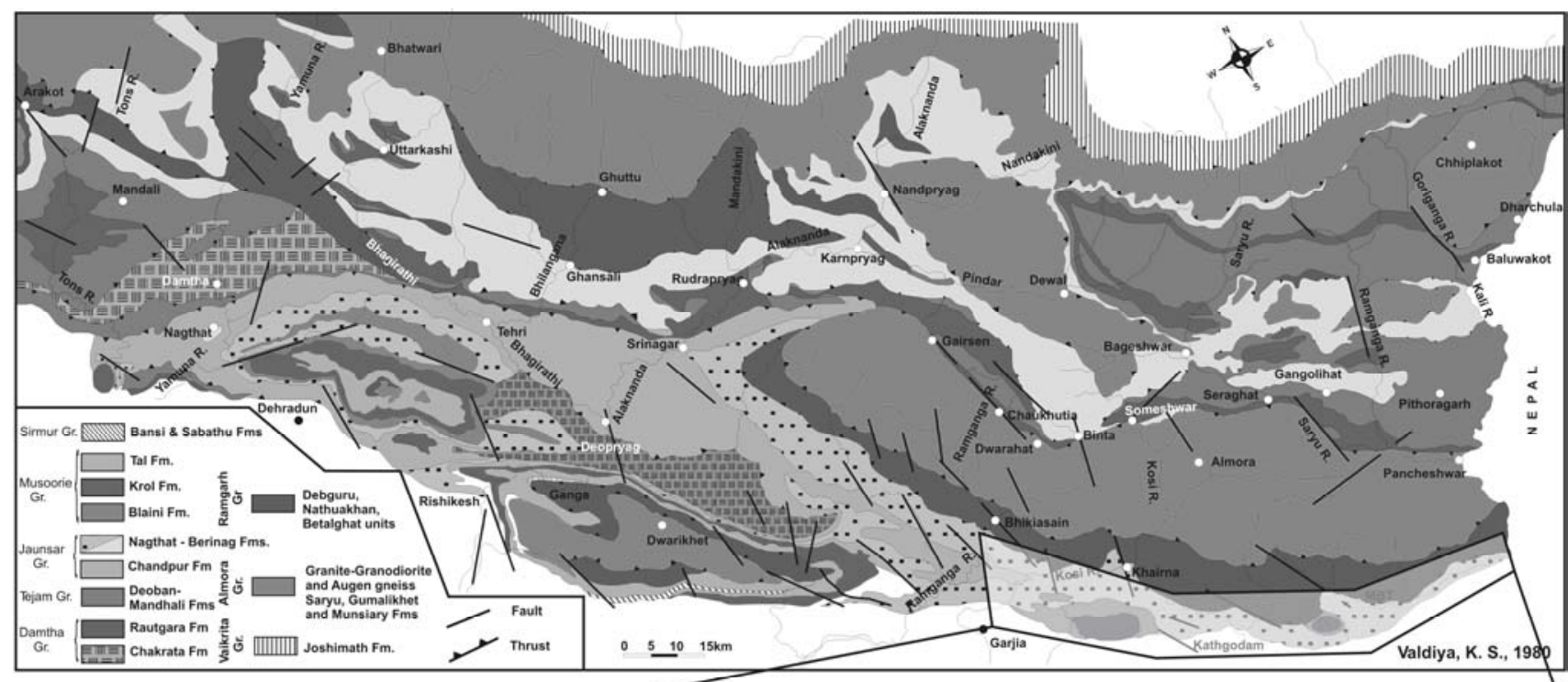

a

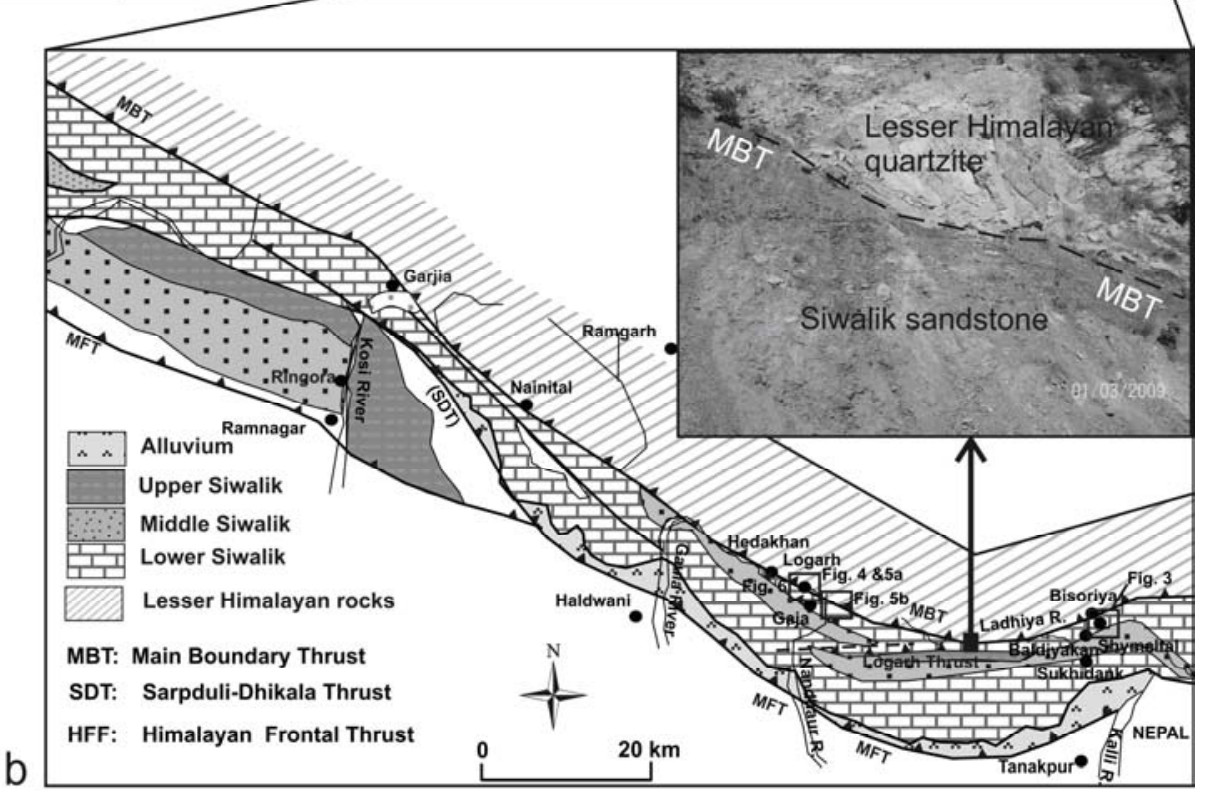

Fig. 1. (a) Regional geological map of Kumaun Himalaya shows (b) Location and Geological background of the Siwalik of Sub- Himalayan region (after Kotlia, 2008). Inset shows position of MBT which separate Siwalik from Lesser Himalayan sequences. 
S
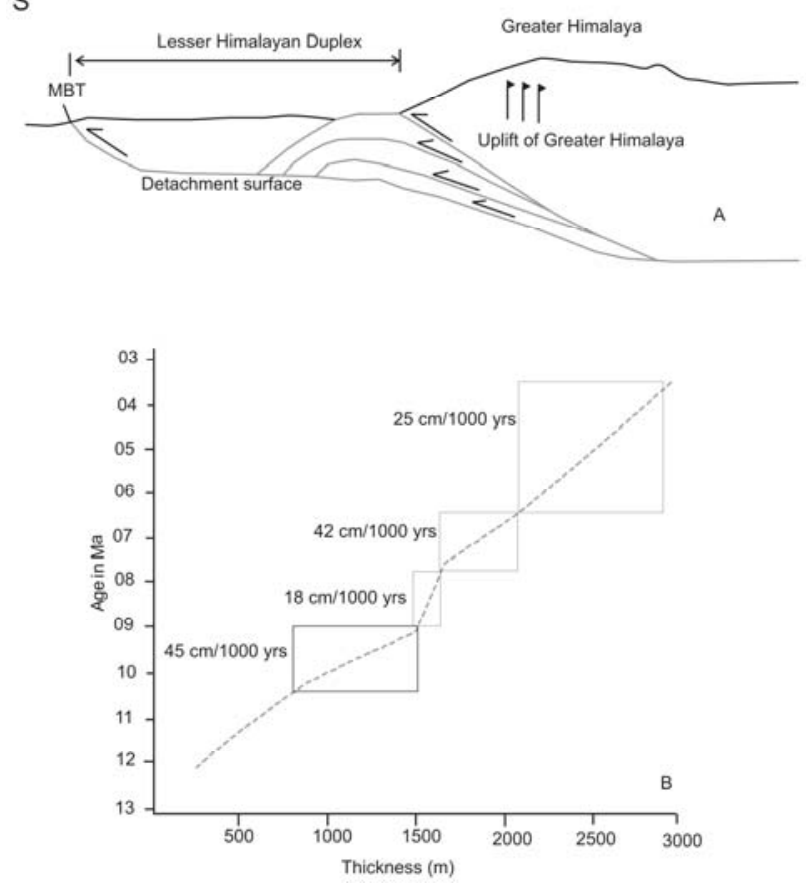

Fig. 2. Schematic model (note to scale) for (a) duplex evolution (modified after Bollinger, et al., 2006) of Lesser Himalaya. (b).Sediment accumulation rate of Siwalik, deduced from the age of thickness verses. The period between 10 and 9ma (after Kotlia, 2008) is marked by highest sediment accumulation rate in the Siwalik region.

branch of the MBT, as for instance in southern Punjab. These secondary fault zones always diverge westward and merge with the MBT towards the east. The irregularity and sinuosity of the fault trace is the evidence of a highly inclined plane. Apart from the recent findings, the MBT with its splay, in many localities particularly in Kumaun sector, behaves as a normal fault as field evidence suggests (Valdiya et al., 1984)

It has been proposed that the southern margin of $\mathrm{Si}$ walik hills got dislocated right laterally for about $2 \mathrm{~km}$ along the trace of MBT (Nakata and Kumhara, 2000). That study in the Kumaun sub Himalayan region is based only on CORONA satellite data interpretation. Through this paper we have tried to relate our field investigations with the aforesaid study. We have tried to bring forward some outstanding landscape features formed as a result of active tectonics in the region.

\section{GEOLOGY}

The southern Kumaun Sub-Himalaya and its environs comprise mainly sedimentary rocks of the Siwalik sequence (Fig. 1a and 1b) It is considered that the Siwaliks are composed of easily erodible molasses that accumulated in the foreland and deformed later by thin skin tectonics (Lave and Avouac, 2000). These are fluvial molassic sediments showing lateral lithofacies variation towards the eastern margin near the India-Nepal border (Kotlia et al., 2001; 2008). Towards the north of the MBT zone, Neoproterozoic-Early Cambrian argilloarenaceous rocks of Lesser Himalaya are exposed which thrust southwards over the Siwalik along the MBT. The Lesser
Himalayan rocks in the MBT zone of Kumaun region show sharp contact of quartzite and Siwalik sandstone (Fig.1b). The Himalayan Frontal Fault lying to the south of Siwaliks shows a N-S shortening along MFT of $21 \pm 2.5 \mathrm{~mm} / \mathrm{yr}$ (Lave and Avouac, 2000) in the Holocene period.

Two episodes of sediment accumulation in Siwalik of Kumaun Himalaya have been observed by Kotlia et al. (2008). Towards the basal and the middle parts, the Kumaun Siwalik shows sediment accumulation rates of $42 \mathrm{~cm} / 1000 y r$ between 6.5 and $8 \mathrm{Ma}$, however, this rate is $45 \mathrm{~cm} / 1000 y r$ during $9-10 \mathrm{Ma}$. Between these events during 8-9 Ma, a vertical uplift has occurred towards the hanging wall of MBT, resulting in an accumulation of conglomerate in the foreland (Meigs et al., 1995). It could be related to the deepest level of erosion of the crystalline thrust sheets during the growth of the basal ramp (Fig. 2a). The tectonic model of Bollinger et al. (2006) suggests development of ramp flat geometry along the basal thrust and physiographic features of Siwalik and Lesser Himalaya. Rapid erosion has taken place parallel to splays of major thrusts. North of the Siwalik range, the topography abruptly rises from an elevation of about 500 to almost $3000 \mathrm{~m}$ along MBT. However between 8-9 Ma, the sediment accumulation rate is very low $(18 \mathrm{~cm} / 1000$ years) (Fig. 2b). Low values of sediment accumulation point at fast uplift and rapid erosion of the Siwalik region along the MBT (Fig. 2b). The southern limit of Siwalik Hills is almost flat and shows rapid base level changes during the Holocene. However the fast rate of base level change can be explained as a tectonic interaction (Lave and Avouac, 2000; Starkel, 2003; Srivastava and Misra, 2008).

\section{GEOMORPHIC SETUP}

In the Siwalik range of Kumaun sub-Himalaya, various geomorphic domains have developed. The foothill zone of Siwalik is occupied by different fan surfaces. Towards the north, Lesser Himalayan sequence is exposed and abruptly uplifted along MBT. The frontal part of the Siwalik is covered with piedmont gravels (Valdiya, 2001; Wobus et al., 2003). The subsidiary faults of MBT are exposed in the eastern limit of Kumaun SubHimalaya near Nepal. The Kali river flows transverse to these faults and displays vertical incision indicating rapid uplift of the channel floor. The Ladhiya river flows parallel to the MBT zone. In this region, four northward dipping surface breaking normal faults have been observed (Fig. 3a). Neotectonic movement along these faults has resulted in the formation of several small lakes. Out of these lakes four are aligned in the same northern most major fault and remains dry in most part of the year while water briefly accumulates during the monsoon (Fig. 3b). Shyamaltal, Mallabanda and Tallabanda lakes were formed due to movement along subsidiary faults. Towards north and south of these faults, massive active landslides are taking place. Vertical displacement of late Pleistocene to early Holocene strath terraces and truncation of colluvial fan have been reported in the Siwalik region by Valdiya (2001). 

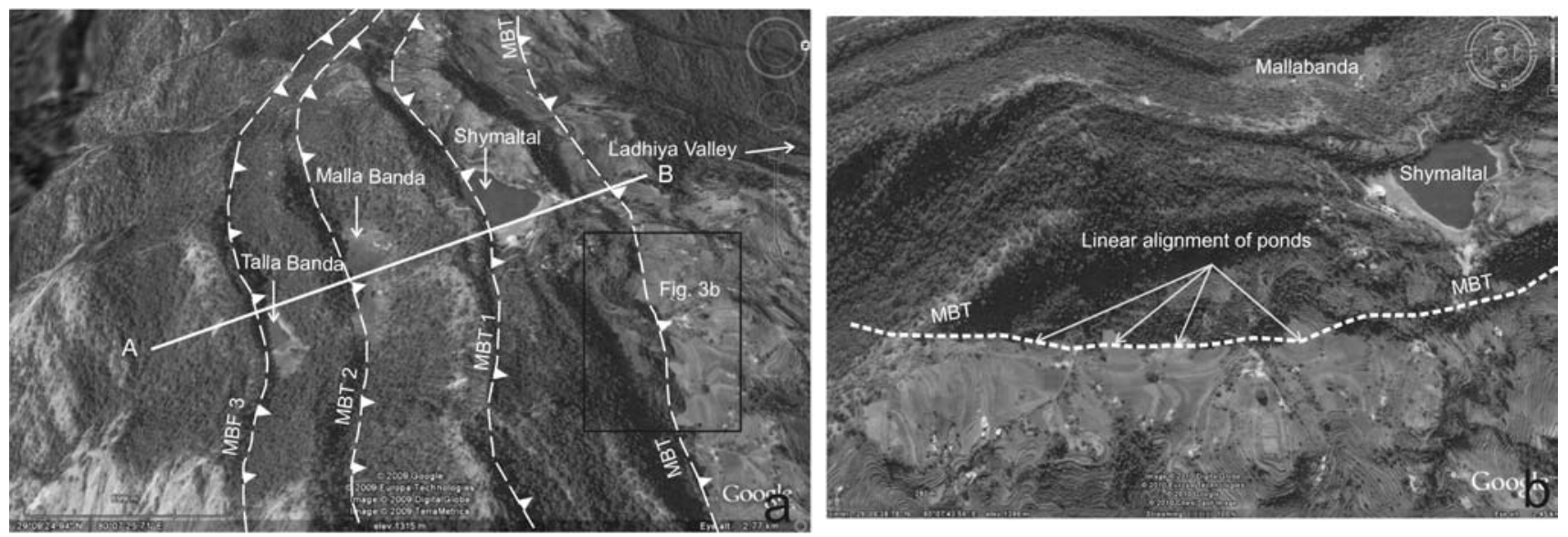

$\mathrm{N}$

S

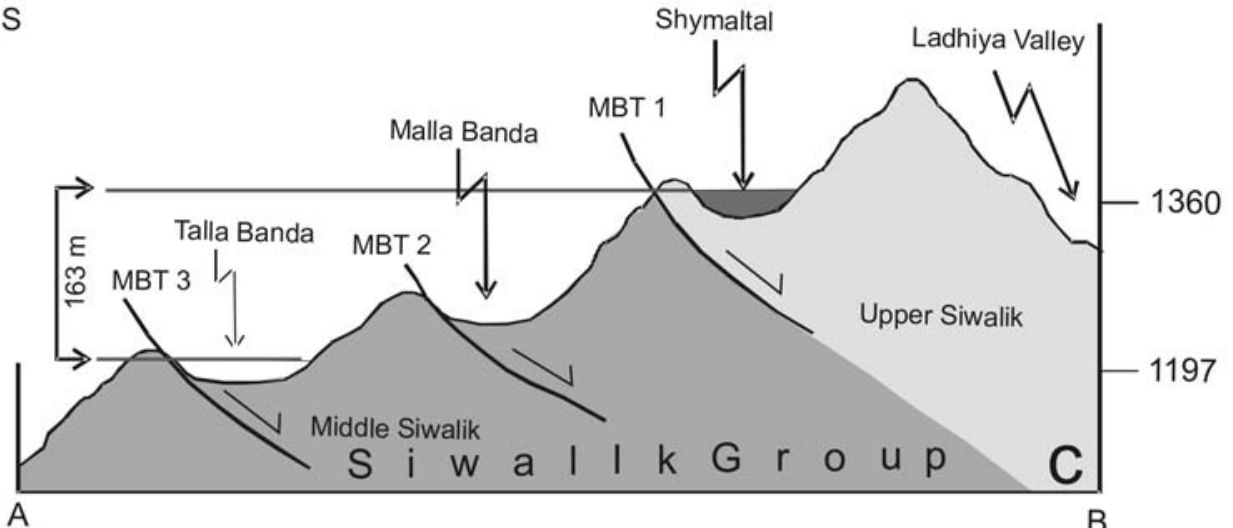

Fig. 3. Satellite Google image shows (a) formation of northward dipping surface breaking imbricated thrusts (Considered as splay of MBT) in MBT zone near Indo-Nepal border. (b) Linear alignment of dry lakes have observed in the zone of MBT. The movement along these thrusts has resulted in (c) splitting of lake system into three i.e. Symaltal, Malla Banda and Talla Banda (Banda stands for depression) along the line A-B.

A number of colluvial fans are seen along the western extension of MBT. These have been mapped in the upper catchment of Gaula river of Kumaun Himalaya. These have coalesced to form a geomorphic surface termed as fan surface. This surface has an area of ca. $5.89 \mathrm{~km}^{2}$ and a steep gradient of $14.51 \%$. The length of the fan surface is $2.29 \mathrm{~km}$ and its width is $745 \mathrm{~m}$. Normal faulting of MBT has resulted in the uplift of the footwall and resulted in faulting of the colluvial fan at Logarh in Gaula valley (Figs. 4a and 5b). A fault scarp of $2.29 \mathrm{~km}$ length cut across the fan, and the active fault scarp measures about $38 \mathrm{~m}$ in height. The constituting materials of the fan (boulders, gravels, rock fragments and sand) are derived from steep slopes of hanging wall. The source basin has an area of ca. $14.04 \mathrm{~km}^{2}$ and the relative height is ca. $987 \mathrm{~m}$. Cut volume of the area is $5356.59 \mathrm{~m}^{3}$ and bearing of the fan surface slope is $201.8^{0}$ (Figs. $4 \mathbf{a}$ and $\mathbf{4 b}$ ). In the source area the Gaula river has incised deeply into the bedrocks to form a V-shaped valley. The valley side slopes consist of two components - a low angle fan slope in the lower part and a high angle steep bedrock cliff in the upper part. The bedrock is exposed in the lowermost and uppermost reaches of the valley. Bedrocks exposed in the fan slope belong to lower Siwalik Group.
The active tectonic movements in the Siwalik ranges of Kumaun have developed a $38 \mathrm{~m}$ thick northward heading fault scarp of the MBT which is clearly visible on the fan surface (Figs. 4b and 5a). Three levels of terraces with a bedrock strath are clearly visible. The $T_{0}$ terrace is found at an elevation of $808 \mathrm{~m}$ a.s.11, whereas $\mathrm{T}_{1}$ and $\mathrm{T}_{2}$ terraces are found at $844 \mathrm{~m}$ a.s.l. and $897 \mathrm{~m}$ a.s.l. (Fig. 5a). The Stream that has laid the fan materials and flowing across the MBT has been deflected westward (present day confluence point and old confluence point are at a distance of almost $1.5 \mathrm{~km}$ ) due to normal faulting. Palaeochannel of the stream of about $280 \mathrm{~m}$ wide is observed in the form of water gaps (Fig. 4a). Streams flowing across the MBT are characterized by a series of knick points in the form of cascading waterfalls.

\section{DISPLACEMENT OF LITHOUNITS}

There seems to be a relation between the formation of the recent morphotectonic features along the MBT and associated NW-SE faults. The model clearly shows the differential movements on active MBT and NW-SE trending fault. Fault scarp has been observed towards the south of MBT near Hedhakhan $\left(29^{\circ} 13^{\prime} 50^{\prime \prime} \mathrm{N}\right.$ and $79^{\circ} 41^{\prime} 11^{\prime \prime E}$ ) in Kumaun Sub-Himalayan region. Two 
main fault strands $\mathrm{F} 1$ and $\mathrm{F} 2$ show reverse faulting with variable dips ranging from $10^{\circ}-45^{\circ}$ towards the northeast. The F1 is a high angle reverse fault with a dip of about $56^{\circ}$, displacing the middle Siwalik sandstone by $1.74 \mathrm{~m}$ (Fig. 6a and 6b). During the propagation of F2, due to compressive tectonic movement, the middle Siwalik rocks have been displaced over the recent sediment. The stratigraphic relationship and pattern of displacement suggest that at least two large tectonic events have occurred in the region after the deposition of the colluvial material.

\section{Lakes in Siwalik, MBT zone}

The outer Kumaun Sub-Himalaya has witnessed the formation of tectonically induced lakes in the footwall of MBT. The strata towards the north of MBT zone dip 30$45^{\circ}$ whereas within the MBT the dip become steeper up to $70-80^{\circ}$. Steeping of strata in the MBT might be due to continuous progressive movement of Indian slab towards north. The hanging wall of initially existed thrust plane slided northward and gave rise normal sense of dip-slip movement, resulted in offsetting of the order of $\sim 100 \mathrm{~km}$ along the strike length. A significant development along the $100 \mathrm{~km}$ traverse of MBT has been the ponding of the streams due to fault movement. Several pieces of evi- dence suggest that stream impoundment in Kumaun SubHimalaya has taken place due to the reactivation of MBT. This phenomenon resulted in the uplift of the footwall of MBT resulting in the formation of series of small lakes. Therefore, the study of lakes is important to understand the tectonic history of the region. In the India-Nepal border near Sukhidang area of Tanakpur region three tectonically induced lakes are found. These lakes are (a) Tallabanda, (b) Mallabanda and (c) Shyamaltal (Figs. 3a and 3b).

\section{Landslides studies}

Various modes of slope failures are common in the hills of southern Kumaun Sub-Himalaya (Bartarya and Valdiya, 1989). The frequency of landslide in the Siwalik range is very high due to the structural and neotectonic activity going on along the MBT zone (Pant and Luirei, 2005; Rawat and Kothyari, 2007). These occur in various extent roughly $70 \mathrm{~km}$ from east in the India-Nepal border to west, south of Nainital Hills in the Kumaun region including displacement of the slope by falls, toppling, slumps, debris flows and slide and land creeping as a function of gravity (Varnes, 1978). The southern hills of Kumaun are susceptible to various types of mass movement.



Fig. 4. (a) Sketch of Logarh area shows morphological parameter of fan surface (b) Google image showing development of terraces surfaces and shifting of small stream from its original channel. within the MBT zone (c) Model showing evolution pattern of fan surface along MBT zone. 

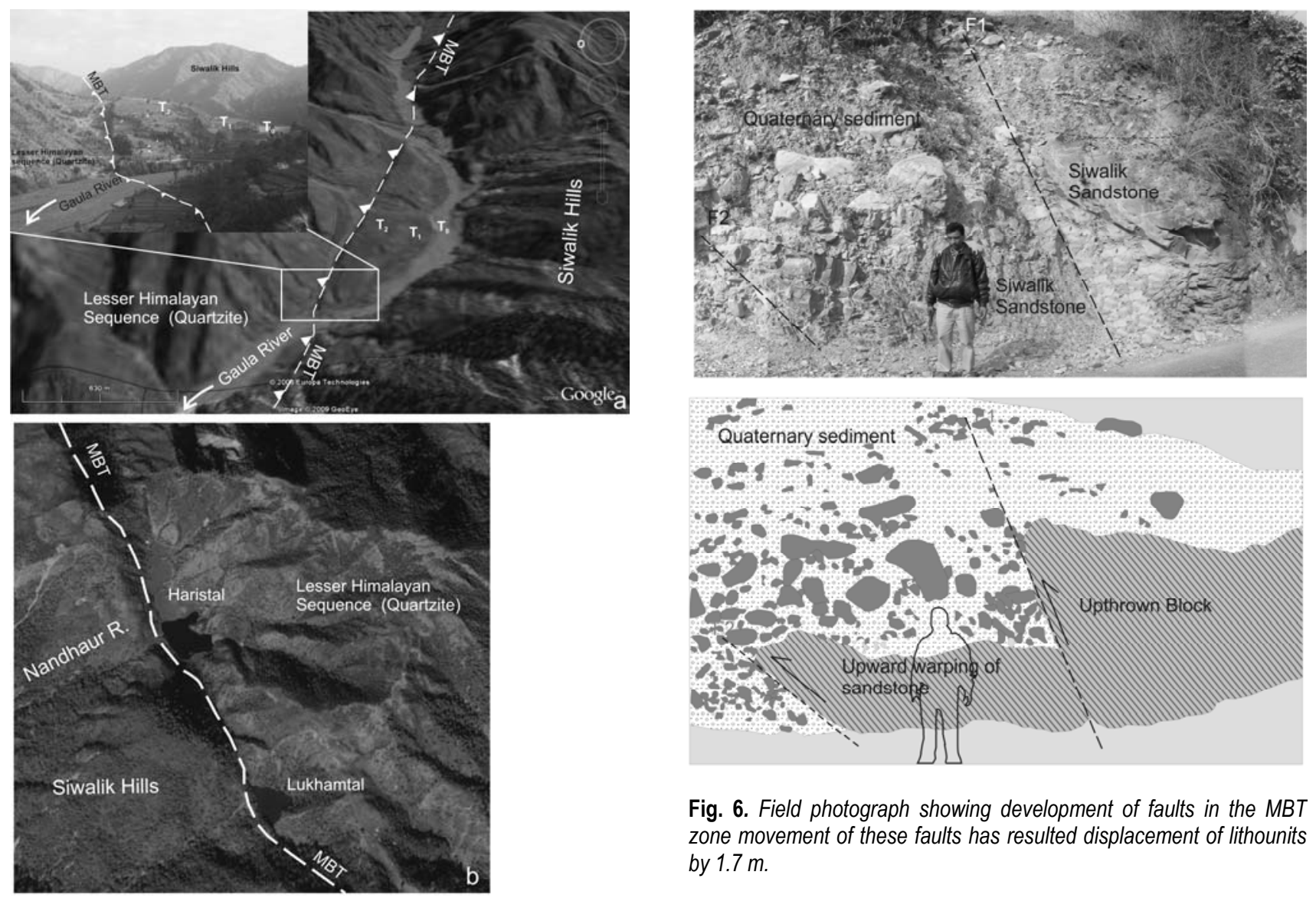

Fig. 6. Field photograph showing development of faults in the MBT zone movement of these faults has resulted displacement of lithounits by $1.7 \mathrm{~m}$.

Fig. 5. (a) Field photograph showing truncation of fan surface within the MBT zone. Satellite image shows formation of colluvial fan along the trace of MBT. (b). Google image shows bird eye view of Haristal and Lukhamtal in MBT zone.

Exposed surfaces of landslides suggest that these take place as a result of the intersection of multiple joint planes in the vicinity of the MBT zone. Neotectonic movements along the MBT have not only made the slopes steeper but have also subjected the rocks in the thrust zone to brittle deformation. This is evident from the multiple joint sets (Fig. 7). These multiple joint planes in the high angle slopes have caused wedge failures. The intersections of the joint planes to be analyzed must be exposed in the slope faces, the plunge of intersection must be less than the dip angle of the slope face and greater than the friction angle of the joint planes (Fig. 7). The safety factor analysis has been done using the formula given by Markland (1972):

$$
F=\frac{\sin \beta}{\sin (\xi / 2)} \frac{\tan \psi}{\tan \psi_{i}},
$$

where $F$ is wedge failure, $\sin \beta / \sin (\xi / 2)$ is the wedge factor and $\tan \psi / \tan \psi_{\mathrm{i}}$ Safety factor of a plane. Safety Factor value greater than 1.00 is assumed to be on the stable side while less than 1.00 is assumed to be unstable (Hoek and Bray, 1977; Markland, 1972). We have analyzed five major landslides in the MBT zone namely (a) Bisoriya, (b) Baldiyakan, (c) Gaja, (d) Logarh and (e) Hedakhan (Table 1).

\section{DISCUSSION AND CONCLUSION}

This paper focuses on the geomorphic development of southern Kumaun Himalayan Siwalik in response to the neotectonic movements along the MBT. Intense tectonic activity has led to the development of some spectacular landscape features which have been brought forward in this paper. The study has shown that the neotectonic movements in Kumaun Sub Himalaya occur along the splays of Main Boundary Thrust (MBT) due to out-ofsequence deformation. The TL date of fault gouges obtained from Kumaun Sub Himalaya indicates its reactivation at $70 \pm 17 \mathrm{ka}$ (Singhvi et al., 1994; Banerjee et al., 1999). Roughly 10-30 m vertical displacement of terraces of the Late Pleistocene to early Holocene terraces has been observed in the MBT zone (Valdiya, 2001 and Valdiya et al., 1984). The vertical uplift rate of terraces has been correlated with the data collected from the terraces at Nandhaur River. Minimum vertical uplift rate of the terraces is estimated to be $5-11 \mathrm{~mm} / \mathrm{yr}$, calculated using elevation of terraces by maximum radiocarbon age of terrace abandonment (Kumar et al., 2006). Most of the displacement in Kumaun Sub- Himalayan region has been recorded between 1404 to 1400 AD (1413 \pm 9 AD) by Kumar et al. (2006). The trench investigation in the frontal region of Kumaun Himalaya by Kumar et al. (2006) suggests that the vertical separation of $\sim 9-13 \mathrm{~m}$ is interpreted to indicate $\sim 18-26 \mathrm{~m}$ of co-seismic slip during last surface rupture. It has been suggested that Kumaun Sub Himalayan region was rocked by a large earthquake of $\mathrm{M}$ $\sim 7.5$ at that time (Kumar et al. 2006). 

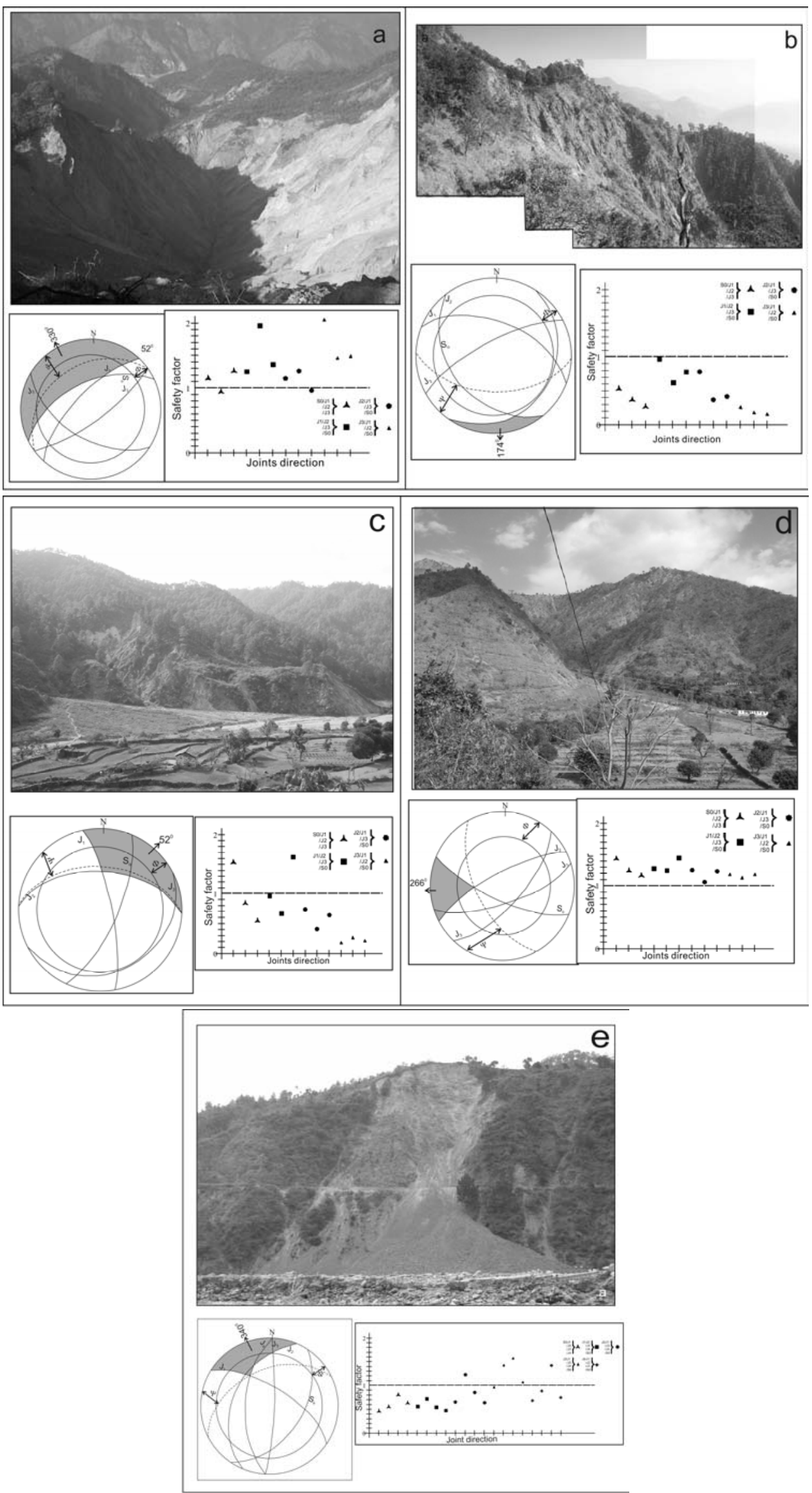

Fig. 7. Field photograph of active landslide within the MBT zone in Kumaun region (a) Bisoriya (b) Baldiyakan, (c) Ghaza, (d) Logadh, (d) Hedakhan. The wedge analysis and safety factor analysis have been done using joints relation with natural slope the friction angle of joints forming the wedge has been assumed to be $23^{\circ}$ for Siwalik sandstone and 250 for Lesser Himalayan Quartzite. In stereographic projection J1. J2. J3 are joint planes, SO bedding plane, $\Phi$ angle of friction, $\psi$ slope angle and Shaded portion represent unstable zone. 
Table 1. Explaining safety factor value of value of landslides observed in Kumaun Sub-Himalayan region.

\begin{tabular}{|c|c|c|c|c|c|}
\hline Landslide & Latitude & Longitude & Safety factor & Average & Description \\
\hline Bisoriya & $29^{\circ} 10^{\prime} 35.59^{\prime \prime}$ & $80^{\circ} 7^{\prime} 47.16^{\prime \prime}$ & 0.99 to 2.009 & 1.339 & $\begin{array}{l}\text { The obtained value is on the safer side but wedge analysis and } \\
\text { field observation indicate instability of the slopes }\end{array}$ \\
\hline Baldiyakan & $29^{\circ} 09^{\prime} 16^{\prime \prime}$ & $80^{\circ} 07^{\prime} 50^{\prime \prime}$ & 0.164 to 0.99 & 0.475 & $\begin{array}{l}\text { Safety Factor suggests high instability of the slope where rock } \\
\text { fall and free fall are still taking place. }\end{array}$ \\
\hline Gaja & $29^{\circ} 14^{\prime} 07.20^{\prime \prime}$ & $79^{\circ} 39^{\prime} 26.93^{\prime \prime}$ & 0.216 to 1.607 & 0.721 & $\begin{array}{l}\text { Both wedge failure analysis and Safety value indicate the } \\
\text { instability of the slope. }\end{array}$ \\
\hline Logarh & $29^{\circ} 14^{\prime} 17^{\prime \prime}$ & $79^{\circ} 40^{\prime} 38^{\prime \prime}$ & 1.046 to 1.46 & 1.233 & $\begin{array}{l}\text { The detached mass has been reactivated in the form of debris } \\
\text { flow and creep movement particularly during monsoon due to } \\
\text { infiltration of water and toe erosion by Gaula river. value is on } \\
\text { the safer side but wedge analysis and field observation indicate } \\
\text { instability of the slope }\end{array}$ \\
\hline Hedakhan & $29^{\circ} 14^{\prime} 09.93^{\prime \prime}$ & $79^{\circ} 39^{\prime} 26.93^{\prime \prime}$ & 0.246 to 1.575 & 0.794 & $\begin{array}{l}\text { Wedge failure analysis shows formation of wedges towards the } \\
\text { open slope surface and plunge of the intersection of the joints } \\
\text { falls within the slipping envelope }\end{array}$ \\
\hline
\end{tabular}

this paper several pieces of evidence (lakes, terraces races, gorges, uplifted terrain and fault scarps) were brought forward which suggest that the MBT has been behaving as a normal fault in Kumaun Sub-Himalayan region. A number of colluvial fans were observed in the upper catchment of river Gaula. Displacement of MBT resulted in the uplift and truncation of colluvial strath along river Gaula. The active tectonic movements in the Siwalik ranges of Kumaun have developed a $38 \mathrm{~m}$ thick northward hading fault scarp of the MBT which is clearly visible on the fan surface. We have tried to develop a conceptual model for the evolution of the colluvial fans in the MBT zone. The fans were formed as a result of faulting and rapid uplift of the hanging wall along the MBT during the first phase. The initial uplift of Lesser Himalayan quartzite took place along MBT. The rapid uplift in the region caused erosion in the uplifted region and deposition in the footwall region of the MBT at a very fast rate (Fig. 4b). In the later phase of tectonic movement, due to gravity sliding and northward heading, a steeply dipping $38 \mathrm{~m}$ thick fault scarp was formed (Fig. 4b). Later the fan surface was dissected during the second phase of tectonic movement. The active deformation along MBT in Sukhidang area has led to the splitting of a lake along its splays to give rise to a peculiar lake system. A hypothetical model has been proposed to explain the origin of these lakes.

A hypothetical model has been proposed to explain the evolution of these lakes. The model suggests that these three lakes may have been connected in the geological past (Fig. 3c). Movements along the splays of MBT have resulted in opening of these lakes along the detachment zone of MBT. Consequently, the lakes were split into three along the splays and the upper Siwalik rocks got uplifted by $163 \mathrm{~m}$ in the region (Fig. 3b). Towards the upper catchments in Nandhaur, two lakes were observed along the trace of MBT namely (a) Harishtal and (b) Lokhambtal. These lakes were formed in the later phase of tectonic movement along the MBT (Fig. 5b). The tectonic model suggests that during the first phase of tectonic movement along MBT, the Lesser Himalayan quartzite thrusted over the Siwalik. In the later phase of tectonic movement, gravity sliding took place. The normal faulting phenomenon of MBT is responsible for uplift and blocking the mouth of the stream to form Haristal (Fig. 5b).

Stream flowing across the MBT has deflected westward leaving behind palaeochannels. Streams flowing across the MBT are also characterized by a series of knick points in the form of cascading waterfalls. The intense tectonic activity along the MBT has made the region susceptible to landslides. The rocks are defined by brittle deformation with multiple joint sets creating an ideal state for wedge failures particularly during monsoon. Stereographic projection of joint planes (wedge failure) and Safety Factor Analysis for each landslide were carried out which indicate that the slopes are unstable and vulnerable.

\section{ACKNOWLEDGEMENTS}

Our sincere thanks to the Dr. B. K. Rastogi Director General, Institute of Seismological Research, Gandhinagar and Head, Department of Geology Kumaun University, Nainital for their support in carrying out this study. PDP is grateful to Department of Science and Techonology, New Delhi for financial assistance under the Research project scheme (No.SR/S4/Es-76/2003/2006). GCK records his sincere gratitude to Prof. L. S. Chamyal, M. S. University Baroda, for his valuable suggestions.

\section{REFERENCES}

Banerjee D, Singhvi A, Pande K, Gogte V and Chandra BP, 1999. Towards a direct dating of fault gouge using luminescence dating technique-methodology and aspect 1999. Current Science 77: 256268.

Bartarya SK and Valdiya KS, 1989. Landslides and erosion in the catchment of the Gaula River, Kumaun Lesser Himalaya, India. Mountain Research and Development 9(4): 405-419.

Bilham R and Gaur VK, 2000. Geodetic contributions of the study of seismotectonics in India. Current Science 79(9): 1259-1269.

Bilham R, Bendic KR and Gaur V, 1998. Geodetic constraints on the translation and deformation of India: Implication for future great Himalayan earthquakes. Current Science 74(3): 213-229.

Bollinger L, Henry P and Avouac JP, 2006. Mountain building in the Nepal Himalaya: Thermal and kinematic model, Earth Planet. Science Letter 244(1-2): 58-71, DOI 10.1016/j.eps1.2006.01.045

Bookhagen B, Thiede R and Strecker MR, 2005. Abnormal Monsoon years and their control on erosion and sediment flux in the high, arid northwestern Himalaya. Earth and Planetary Science Letters 231(1-2): 31-146, DOI 10.1016/j.epsl.2004.11.014. 
Burbank DW and Raynolds RGH, 1988. Stratigraphic keys to the timing of thrusting in terrestrial foreland basin: Application to the Northwestern Himalaya. In: Kleinspshn KL and Paola C, eds., New perspective in basin analysis. New York, Springer-Verlag: 331-351.

Hodges KV, Parrish RR and Searle MP, 1996. Tectonic evolution of the central Annapurna Range, Nepalese Himalaya. Tectonics 15(6): 1264-1291, DOI 10.1029/96TC01791.

Hodges KV, Wobus C, Ruhl K, Schilsdgen T and Whipple K, 2004. Quaternary deformation, river steepening and heavy precipitation at the front of the Higher Himalaya range, Earth and Planetary Science Letters 220(3-4): 379-389, DOI 10.1016/S0012821X(04)00063-9.

Hoek E and Bray JW, 1977. Rock slope. London, Engineering Institute of Mining and Metallurgy: 290pp.

Kayal JR, 2001. Microearthquake activity in some parts of the Himalaya and the tectonic model. Tectonophysics 339(3-4):331-351, DOI 10.1016/S0040-1951(01)00129-9.

Kotlia BS, Nakayama K, Bhalla MS, Phartyal B, Kosaka T, Joshi M, Sanwal J and Pande RN, 2001. Lithology and magnetic stratigraphy of the Lower-Middle Siwalik succession between Kathgodam and Ranibag, Kumaun Himalaya. Journal of the Geological Society of India 58(5): 411-423.

Kotlia BS, Phartiyal B, Kosaka T and Bohra A, 2008. Magnetostratigraphy and lithology of Miocene-Pliocene Siwalik deposits between Tanakpur and Sukhidang, southeastern Uttarakhand Himalaya, India. Himalayan Geology 29(2): 127-136.

Kumar S, Wesnousky SG, Rockwell TK, Briggs RW, Thakur VC and Jayangondaperumal R, 2006. Paleoseismic evidences of grate surface rupture earthquakes along the Indian Himalaya. Journal of Geophysical Research 111: B03304, DOI 10.1029/2004JB003309.

Lave J and Avouac JP, 2000. Active folding of fluvial terraces across the Siwaliks Hills, Himalayas of central Nepal. Journal of Geophysical Research 105(B3): 5735-5770, DOI 10.1029/1999JB900292.

Macfarlane AM, 1993. Chronology of tectonic events in the crystalline core of the Himalaya, Langtang National Park, central Nepal. Tectonics 12(4): 1004-1025, DOI 10.1029/93TC00916.

Malik JN and Nakata T, 2003. Active faults and related Late Quaternary deformation along the Northwestern Himalayan Frontal Zone, India. Annals of Geophysics 46(5): 917-936

Markland JT, 1972. A useful technique for estimating the stability of rock slopes when the rigid wedge sliding type of failure is expected. Imperial College, Rock Mechanics Research Report 19: $10 \mathrm{pp}$.

Meigs AJ, Burbank DW and Beck RA, 1995. Middle-late Miocene (>10
Ma) formation of the Main Boundary Thrust in the western Himalaya. Geology 23(5): 423-462, DOI 10.1130/00917613(1995)023<0423:MLMMFO >2.3.CO;2

Molnar P, 2003. Geomorphology: Nature, nurture and landscape. $\mathrm{Na}$ ture 426: 612-614, DOI 10.1038/426612a.

Khwaja M and Khwaja AA, 2005. Seismic activity along the Main Boundary Thrust (MBT), Pakistan. Geological Bulletin University of Peshwar 38: 23-30.

Nakata T, 1972. Geomorphic History and Crustal movements of the Himalaya. Institute of Geography, Tohuku University, Aendai: $77 \mathrm{pp}$.

Nakata T. and Kumahara, Y., 2002. Active Faulting in and around Himalaya, and its significance in the collision tectonics Active fault Research 22: 7-16.

Pant PD and Luirei K, 2005. Malpa rockfalls of $18^{\text {th }}$ August 1998 in northeastern Kumaun Himalaya. Journal of the Geological Society of India 54: 415-420.

Pollitz F, Banerjee P, Grijalva K, Nagarajan B and Burgmann R, 2008. Effect of 3-D viscoelastic structure on post seismic relaxation from the $2004 \mathrm{M}=9.2$ Sumatra earthquake. Geophysical Journal International 173(1): 189-204, DOI: $10.1111 / \mathrm{j} .1365$ 246X.2007.03666.X

Rawat KS and Kothyari GC, 2007. The mass movement disaster at the Ampadav locality in the Kumaun Siwaliks, Nainital, and Uttaranchal. In: Saklani PS, ed., Himalaya: Geological Aspect 5: 149-157.

Seeber L, Armbruster AG and Quittmeyer J, 1981. Seismicity and continental subducion in the Himalayan Arc. In: Gupta HK and Delany FM, eds., Zagros, Hindukush, Himalya. Geodynamic Evolution, Geodynamic Series 3: 215-242.

Singhvi AK, Banerjee D, Pande K, Gogte V and Valdiya KS, 1994. Luminescence studies on neotectonic events in south-central Kumaun Himalaya - A feasibility study. Quaternary Science Reviews 13(5-7): 595-600, DOI 10.1016/0277-3791(94)90083-3.

Srivastava P and Misra DK, 2008. Morpho-sedimentary records of active tectonics at the Kameng river exit, NE Himalaya. Geomorphology 96(1-2): 187-198, DOI 10.1016/j.geomorph.2007.07.019

Starkel L, 2003. Climatically controlled terraces in uplifting mountain areas. Quaternary Science Reviews 22: 2189-2198, DOI 10.1016/S0277-3791(03)00148-3.

Valdiya KS, 2001. Reactivation of terrain-defining boundary thrusts in Central sector of the Himalaya: Implication. Current Science 81(11): 1418-1430.

Valdiya KS, 2003. Reactivation of Himalayan frontal fault: Implication. Current Science 85(7): 1031-1040. 